\title{
Lipid and protein composition of outer and inner membranes in wild-type strains and nod mutants of Rhizobium meliloti
}

\author{
C. Hubac,${ }^{1 *}$ D. Guerrier, ${ }^{1}$ J. Ferran,${ }^{1}$ A. Trémolières ${ }^{2}$ and A. Kondorosi ${ }^{1,3}$ \\ ${ }^{1}$ Institut des Sciences Végétales and ${ }^{2}$ Laboratoire de Biochimie Fonctionnelle des Membranes Végétales, CNRS, 91198 \\ Gif-sur-Yvette Cedex, France \\ ${ }^{3}$ Institute of Genetics, Biological Research Center, Hungarian Academy of Sciences, 6701 Szeged, Hungary
}

(Received 26 February 1992 ; revised 21 April 1992; accepted 29 May 1992)

\begin{abstract}
The glycerolipid and protein compositions of the outer and inner membranes of Rhizobium meliloti were studied. The wild-type $R$. meliloti strain Rm41 was shown to contain three phospholipids characteristic for most Gramnegative bacteria, phosphatidylethanolamine, phosphatidylglycerol and diphosphatidylglycerol, this last compound being concentrated into the inner membrane. As in several bacteria interacting with plants, the presence of phosphatidylcholine, phosphatidyl- $N$-monomethylethanolamine and phosphatidyl- $N, N$-dimethylethanolamine was also demonstrated. Induction of the nod genes by luteolin did not affect the lipid composition and no difference in lipid composition was found between the wild-type strain and a number of $\mathrm{Nod}^{-}$and Fix ${ }^{-}$mutants tested. Protein analysis of the inner and outer membranes showed that they exhibit very different patterns with several bands specific for one or the other membrane. A Nod ${ }^{-}$mutant carrying a large deletion in the symbiotic megaplasmid pRme41b showed differences in the protein patterns even before induction by luteolin, indicating that this megaplasmid codes for several membrane proteins. When the nod genes of strain $R \mathrm{~m} 41$ were induced by luteolin, two new bands at around $60 \mathrm{kDa}$ and $44 \mathrm{kDa}$ appeared in both the outer and the inner membranes. By using a strain overexpressing the nod genes and the technique of immunoblotting with antibodies against NodC, it was confirmed that the $44 \mathrm{kDa}$ band corresponded to the NodC protein. This protein was not found in a nodC::Tn5 mutant. This work represents the first step in the characterization of modifications induced by luteolin treatment at the membrane level.
\end{abstract}

\section{Introduction}

Rhizobia, such as Rhizobium meliloti, are Gram-negative bacteria belonging to the family Rhizobiaceae. The infection of roots of leguminous plants by Rhizobium leads to the formation of $\mathrm{N}_{2}$-fixing nodules. The nodulation process consists of several stages which can be dissected by using bacterial and plant mutants. Bacterial surface components play an important role in several of these stages (Robertson et al., 1985).

The cell envelope of Gram-negative bacteria contains three essential layers, namely the cytoplasmic or inner membrane, the peptidoglycan or murein layer and the outer membrane (de Maagd, 1989). The membrane

\footnotetext{
* Author for correspondence. Tel. 169823603 ; fax 169823695.
}

Abbreviations: DG, diglyceride; TG, triglyceride; LPL, lysophospholipid; PC, phosphatidylcholine; PE, phosphatidylethanolamine; PG, phosphatidylglycerol; DPG, diphosphatidylglycerol; PS, phosphatidylserine; MMPE, phosphatidyl- $N$-monomethylethanolamine; DMPE, phosphatidyl- $N, N$-dimethylethanolamine. proteins comprise approximately $15-25 \%$ of the total cell proteins (Lugtenberg \& van Alphen, 1983). The cytoplasmic membrane contains phospholipids and proteins in about equal amounts (Osborn et al., 1972; Osborn \& Wu, 1980). The outer membrane also contains, in addition to phospholipids and proteins, lipopolysaccharide as a major constituent. The outer membrane is covalently attached to the peptidoglycan layer through lipoprotein molecules (Braun \& Hantke, 1974).

Our knowledge of the biochemical structure of membranes in Rhizobium is still scanty, as indicated by the small number of publications on the subject. Gerson \& Patel (1975) described the composition of neutral lipids and phospholipids of two Rhizobium strains in their free-living state and in symbiosis with Lotus pedunculatus. Miller \& Tremblay (1983) compared the cytoplasmic membrane composition of free-living $R$. meliloti with that of the peribacteroid membrane. Membrane protein profiles (unseparated membranes) of R. leguminosarum, R. meliloti and Agrobacterium tumefaciens were analysed by de Maagd et al. (1988). Separated 
membranes have been studied only in $R$. leguminosarum in the exponential phase (de Maagd \& Lugtenberg, 1986).

We have analysed the lipid and protein composition of the outer and the inner membranes of different wild-type and $\mathrm{Nod}^{-}$or $\mathrm{Fix}^{-}$mutant strains of $R$. meliloti at different stages of growth. The strains were analysed before and after exposure to luteolin, a flavone produced by seed exudates of the host plant Medicago sativa, which induces the expression of nod genes (Peters et al., 1986). Here we report on the glycerolipid and protein composition of the separated membranes. In agreement with the previous results of John et al. (1988), we found that the NodC protein is a membrane protein, but it was detected both in the outer and in the inner membranes.

\section{Methods}

Bacterial strains and plasmids. These are listed in Table 1.

Medium and culture conditions. Liquid cultures were grown at $30^{\circ} \mathrm{C}$ with aeration in tryptone-yeast (TA) medium (Kondorosi et al., 1977). Growth of bacteria was followed spectrophotometrically by measuring the optical density at $540 \mathrm{~nm}$. Samples were taken at different stages during the exponential phase and at the plateau of growth. For nod gene induction, luteolin $\left(3^{\prime}, 4^{\prime}, 5,7\right.$-tetrahydroxyflavone) was added to the bacterial cultures at a concentration of $10 \mu \mathrm{M}$ and incubation was continued for $8 \mathrm{~h}$.

Fractionation of membranes. An overnight bacterial culture $(500 \mathrm{ml})$ was harvested by centrifugation at $5000 \mathrm{~g}$ for $30 \mathrm{~min}$ at $4{ }^{\circ} \mathrm{C}$, washed twice in $0.9 \% \mathrm{NaCl}, \mathrm{pH}$ adjusted to 7.4 with $\mathrm{NaOH}$, and suspended in $10 \mathrm{ml} 50 \mathrm{~mm}$-Tris/HCl (pH 8.5), with $0.2 \mathrm{~mm}$-dithiothreitol (DTT), supplemented with $0.2 \mathrm{mg}$ deoxyribonuclease $\mathrm{I}$ and ribonuclease A $\mathrm{ml}^{-1}$. The cells were broken by two passages through a French pressure cell (about $70 \mathrm{MPa}$ ). The broken cell suspension was centrifuged for $10 \mathrm{~min}$ at $3000 \mathrm{~g}$ to remove unbroken cells. The supernatant containing the unseparated membranes was centrifuged for $2 \mathrm{~h}$ at $130000 \mathrm{~g}$. The resulting pellet was suspended in $1 \mathrm{ml} 20 \%(\mathrm{w} / \mathrm{v})$ sucrose containing 5 mM-EDTA, 0.2 mM-DTT (pH 7.5), 5\% (v/v) mercaptoethanol and layered on top of a discontinuous density gradient, consisting of $2 \mathrm{ml}$ of decreasing concentrations of sucrose: $55-50-45-40-35 \%(w / w)$. This gradient was centrifuged for $17 \mathrm{~h}$ at $130000 \mathrm{~g}$ in a Beckman SW 41 rotor, following a modified technique of de Maagd \& Lugtenberg (1986), and $0.5 \mathrm{ml}$ fractions were collected. The protein content was determined by the method of Bradford (1976).

Two membrane markers, the KDO (2-ketodeoxyoctonate) content for the outer membrane and the NADH oxidase activity for the inner membrane (de Maagd \& Lugtenberg, 1986) were used. By following the profile of the protein content, the outer membrane was found in the $55 \%$ sucrose fractions, and the inner membrane in the $35 \%$ sucrose fractions (Fig. 1).

Lipid analysis. Lipids were extracted according to Bligh \& Dyer (1959). Total fatty acids in the fractions corresponding to the outer or to the inner membrane were transmethylated with methanolic $\mathbf{B F}_{3}$ according to Metcalfe et al. (1966), and the different fatty acid methyl esters were analysed by capillary GLC on a Carbowax column at $170^{\circ} \mathrm{C}$. For measuring the amounts of fatty acids, heptadecanoic acid $(17: 0)$ was added as an internal standard before methylation. Polar lipids were separated by TLC (Merck G 60) in chloroform/acetone/ methanol/acetic acid/water $(10: 4: 2: 2: 1$, by vol.) (Trémolières \& Lepage, 1971). Chromatography was stopped when the solvent had ascended three-quarters of the height of the plate. After drying, neutral lipids were separated by further chromatography on the same plate in light petroleum/diethyl ether/acetic acid (175:75:1, by vol.) (Mangold, $1961,1964)$. Lipids were visualized with iodine vapour, primuline in UV light and phosphate spray reagent. Ninhydrin was used for the detection of amino groups in lipids, and the Dragendorff reagent for detection of phosphatidylcholine (Kates, 1986). After visualization the bands were scraped off, saponified, methylated and analysed by gas liquid chromatography. Fatty acid content was measured by adding a known amount of heptadecanoic acid as an internal standard to each lipid sample scraped from the plate. Two-dimensional chromatography was also carried out by the method of Thompson et al., (1983) in the first dimension and by the method of Trémolières \& Lepage (1971) in the second dimension. Only the glycerolipids were analysed.

Protein analysis and immunoblotting. Samples for monodimensional electrophoresis were prepared directly from the peak of the sucrose gradient with $1 \%(\mathrm{w} / \mathrm{v})$ SDS and $5 \%(\mathrm{v} / \mathrm{v})$ mercaptoethanol. Samples were routinely heated for $10 \mathrm{~min}$ at $100^{\circ} \mathrm{C}$. Slots were loaded with $5 \mu \mathrm{g}$ protein samples (measured by the Bradford method) before adding SDS and mercaptoethanol. Protein fractions were analysed by SDS-

Table 1. R. meliloti strains and plasmid

\begin{tabular}{|c|c|c|c|c|}
\hline $\begin{array}{l}\text { Rm41 } \\
\text { AK631 } \\
\text { EK698 } \\
\text { EK1261 }\end{array}$ & $\begin{array}{l}\text { Rm41 exoB } \\
\text { AK631 nolR::Tn5 } \\
\text { EK698(pEK327) }\end{array}$ & $\begin{array}{l}\text { Nod }^{+} \text {Fix }^{+} \\
\text {Nod }^{+} \text {Fix }^{+} \\
\text {Nod }^{+} \text {Fix }^{+}\end{array}$ & & $\begin{array}{l}\text { Original isolate by K. Szende and F. Ördögh } \\
\text { Kondorosi et al. (1989) } \\
\text { Kondorosi et al. (1989) } \\
\text { Obtained from E. Kondorosi }\end{array}$ \\
\hline $\begin{array}{l}\text { AK } 985 \\
\text { AK } 1492 \\
\text { TF } 178\end{array}$ & $\begin{array}{l}\text { AK631 fix-540 } \\
\text { AK631 fix-23 } \\
\text { AK631 fix-2 }\end{array}$ & $\begin{array}{l}\text { Nod }^{+} \text {Fix }^{-} \\
\text {Nod }^{+} \text {Fix }^{-} \\
\text {Nod }^{+} \text {Fix }^{-}\end{array}$ & $\begin{array}{r}100 \% \\
85 \% \\
86 \%\end{array}$ & $\begin{array}{l}\text { Forrai et al. }(1983) \\
\text { Banfalvi et al. }(1981) \\
\text { Forrai et al. }(1983)\end{array}$ \\
\hline $\begin{array}{l}\text { EK } 1042 \\
\text { EK } 1702 \\
\text { ZB138 }\end{array}$ & $\begin{array}{l}\text { AK631 nod } C:: \operatorname{Tn} 5 \\
\text { AK631 nodC::Tn5(pEK } 327) \\
\text { nod-nif deletion derivative } \\
\text { of AK } 631\end{array}$ & $\begin{array}{l}\text { Nod }^{-} \\
\text {Nod- }^{-} \\
\text {Nod }^{-}\end{array}$ & & $\begin{array}{l}\text { Kondorosi et al. (1992) } \\
\text { Obtained from E. Kondorosi } \\
\text { Banfalvi et al. (1981) }\end{array}$ \\
\hline pEK 327 & $\begin{array}{l}\text { pLAFRI carrying } \\
\text { nodFEGH } P Q D 3 \text { and } s y r M\end{array}$ & & & Schultze et al. (1992) \\
\hline
\end{tabular}

$* 2 \mathrm{~d}$ delay in nodulation. 


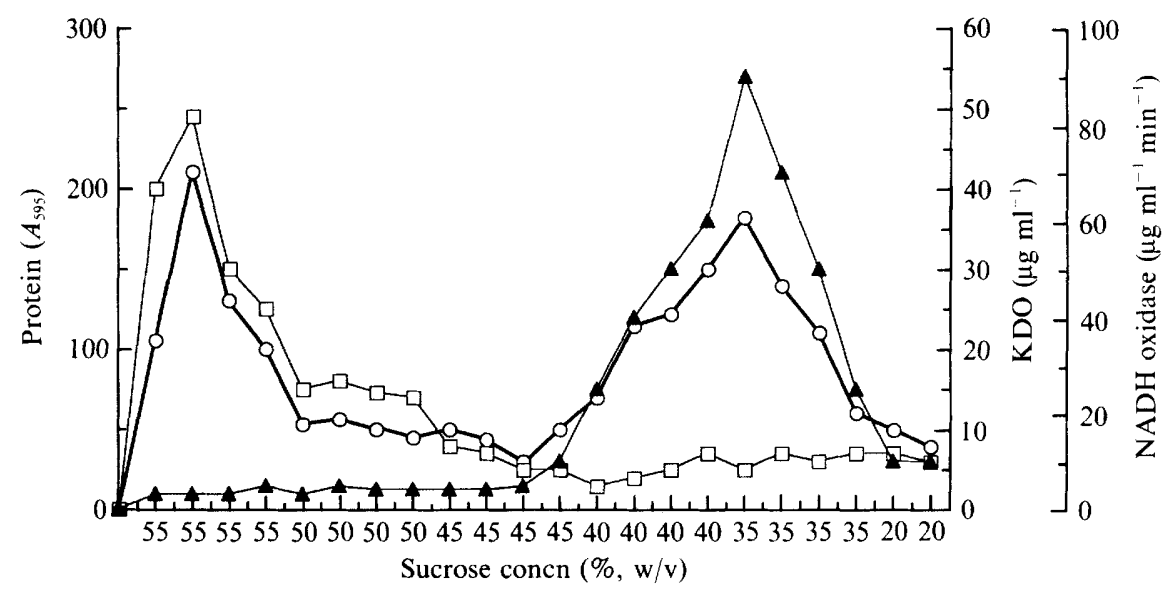

Fig. 1. Isopycnic sucrose density gradient centrifugation of cell membranes of $R$. meliloti 41 . Bacteria were disrupted with a French pressure cell. The outer membrane was localized in the heavy fractions and the inner membrane in the light fractions. The protein content (O) was read at $A_{595}$ by the Bradford (1976) method. For localizing the outer and the inner membranes, the KDO (2ketodeoxyoctonate) content $(\square)$ and the NADH oxidase activity $(\boldsymbol{A})$ were used as markers.

PAGE in $1.5-\mathrm{mm}$-thick gels of 4 and $15 \%(\mathrm{w} / \mathrm{v})$ acrylamide in the stacking and running gels, respectively. Gels were stained with silver nitrate (Blum et al., 1987).

Polyclonal antibodies against a fusion protein between the hydrophobic domain of the NodC protein and the $\lambda$ CI repressor (John et al., 1985,1988 ) were kindly furnished by M. John and J. Schmidt (Max Planck Institute, Köln, Germany).

Proteins were transferred electrophoretically to nitrocellulose (Towbin et al., 1979) and the membranes with immobilized proteins were incubated for $1 \mathrm{~h}$ at room temperature in $10 \mathrm{mM}$ - Tris/ $\mathrm{HCl}(\mathrm{pH} \mathrm{7.4)}$ containing $0.9 \% \mathrm{NaCl}$ (TBS) and $1 \%(\mathrm{w} / \mathrm{v})$ gelatine. The membranes were incubated overnight with a 1:400 dilution of the monospecific antibodies in TBS containing $1 \%$ gelatine at $30{ }^{\circ} \mathrm{C}$ with shaking. After four washes $(10 \mathrm{~min}$ each) with TBS containing $0.1 \%$ Tween 20 (TTBS), the blot was incubated for $1 \mathrm{~h}$ with $1: 500$ diluted rabbit antiIgG $(\mathrm{H}+\mathrm{L})$ peroxidase. After four washes $(10 \mathrm{~min}$ each $)$ in TTBS, the chloronaphtholperoxidase activity was detectable (Towbin et al., 1979).

\section{Results}

\section{Lipid composition of $R$. meliloti wild-type and nod mutants}

The fatty acid composition of the wild-type strain AK631 was analysed at different stages of growth. As shown in Table 2, the proportion of the main component, $18: 1(11 \mathrm{c})$ (cis-vaccenic acid) started to increase at the beginning of growth, and decreased from 84 to $68 \%$ over the late exponential growth phase to the stationary phase. There was a corresponding increase of $19: \mathrm{cy}$ (lactobacillic acid) from $2 \%$ to $20 \%$. This is in agreement with the analysis of Mackenzie et al. (1979) on $R$. leguminosarum. The percentages of $16: 0$ (palmitic acid), 16:1(9c) (palmitoleic acid) and 18:0 (stearic acid) decreased slightly during growth. Minor fatty acids were always detected. A fatty methyl ester eluting just before
Table 2. Relative fatty acid composition during growth of the wild-type strain AK631

\begin{tabular}{|c|c|c|c|c|c|}
\hline \multirow{3}{*}{$\begin{array}{l}\text { Fatty } \\
\text { acid }\end{array}$} & \multirow[b]{3}{*}{$\mathrm{OD}_{540}$} & \multicolumn{4}{|c|}{ Percentage total fatty acids } \\
\hline & & \multicolumn{3}{|c|}{ Exponential phase } & \multirow{2}{*}{$\frac{\text { Stationary phase }}{1.7}$} \\
\hline & & $0 \cdot 1$ & $0 \cdot 3$ & 0.8 & \\
\hline$\leqslant 15$ & & $9 \cdot 2$ & $6 \cdot 1$ & $3 \cdot 3$ & $1 \cdot 2$ \\
\hline $16: 0$ & & $10 \cdot 0$ & $8 \cdot 4$ & $4 \cdot 2$ & $6 \cdot 4$ \\
\hline $16: 1(9 c)$ & & $2 \cdot 6$ & $2 \cdot 9$ & $1 \cdot 3$ & 1.0 \\
\hline $16: 2 \pm 17: c y$ & & $2 \cdot 9$ & 1.4 & 1.4 & tr. \\
\hline $18: 0$ & & $5 \cdot 3$ & $5 \cdot 1$ & $3 \cdot 3$ & 3.6 \\
\hline $18: 1(11 \mathrm{c})$ & & $66 \cdot 0$ & $73 \cdot 4$ & $84 \cdot 3$ & $68 \cdot 4$ \\
\hline $19: c y$ & & $0 \cdot 8$ & $1 \cdot 3$ & $2 \cdot 4$ & $20 \cdot 0$ \\
\hline Unknown & & $3 \cdot 0$ & 1.5 & $0 \cdot 5$ & tr. \\
\hline
\end{tabular}

that of 17:0 in GLC and not reported previously could be $16: 2$ [it can be recalled that $16: 2$ has been found as a fatty acid of the Nod factor (Lerouge et al., 1990)]; another unidentified fatty ester migrated just before 18:0. Two other fatty esters were also detected, with longer retention times than $19: \mathrm{cy}$, which has been previously reported; one of them could be the 11-Me-18:1 reported by Mackenzie et al. (1979), the other could be a branched fatty acid reported in $R$. meliloti by Gerson et al. (1975). Based on the demonstrated dependence of the fatty acid composition on the growth phase, further studies were carried out at a well defined stage of growth (OD 0.7). The fatty acid profiles were similar for all the studied strains of $R$. meliloti, especially Rm41, AK631, AK1492 and ZB138.

The lipid composition was monitored by TLC throughout growth of the bacteria until the stationary 


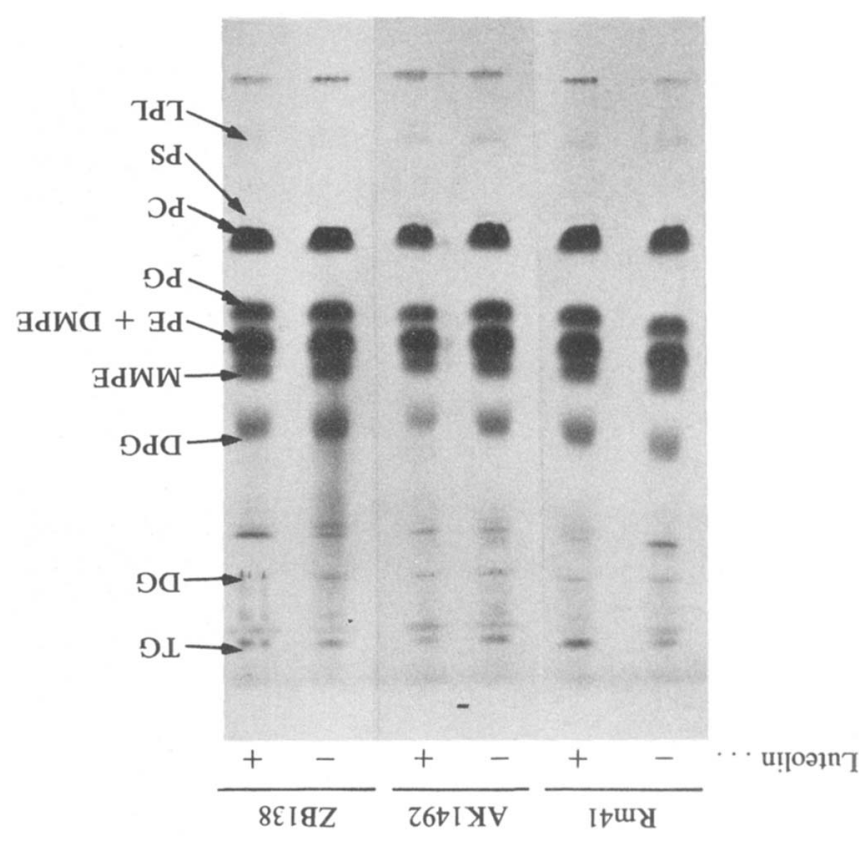

Fig. 2. Lipid classes of whole bacteria in the wild-type strain Rm41 and in the mutants AK1492 and ZB138, as determined by TLC. Bacteria were grown in the presence or absence of luteolin. The main lipid classes were diphosphatidylglycerol (DPG), phosphatidylethanolamine (PE), phosphatidylglycerol (PG), phosphatidylserine (PS), phosphatidylcholine (PC), triglyceride (TG), diglyceride (DG), phosphatidyl- $N$-monomethylethanolamine (MMPE) and phosphatidyl$N, N$-dimethylethanolamine (DMPE). Lipids were visualized by iodine vapour.

phase. No appreciable change was detected in the different luteolin-induced or -uninduced strains: wildtype $\mathrm{Nod}^{+} \mathrm{Fix}^{-}$strains (Rm41 and AK631) and $\mathrm{Nod}^{+}$ Fix- (AK1492) and Nod $^{-}$(ZB138) mutants (Fig. 2). The main lipid classes detected were diphosphatidylglycerol (DPG), phosphatidylethanolamine (PE), phosphatidylglycerol (PG), phosphatidylcholine (PC). Two neutral lipids were tentatively identified as triglyceride (TG) and diglyceride (DG), and a minor lipid reacting positively with ninhydrin was detected just below PC, migrating exactly as a standard phosphatidylserine (PS).

Analysis of the wild-type strain AK631 by twodimensional TLC allowed us to detect three lipids in the region of phosphatidylethanolamine (Fig. 3); the most abundant one, reacting positively with ninhydrin, was PE. The spot just below PE was identified as phosphatidyl- $N, N$-dimethylethanolamine (DMPE). The third spot just above PE, representing about $8 \%$ of the total lipid content, was identified as phosphatidyl- $N$-monomethylethanolamine (MMPE).

Identification of PC and MMPE was confirmed by isolation of the compounds and analysis by proton NMR spectroscopy and chemical ionization mass spectrometry (Varenne et al., 1985). These two methods showed

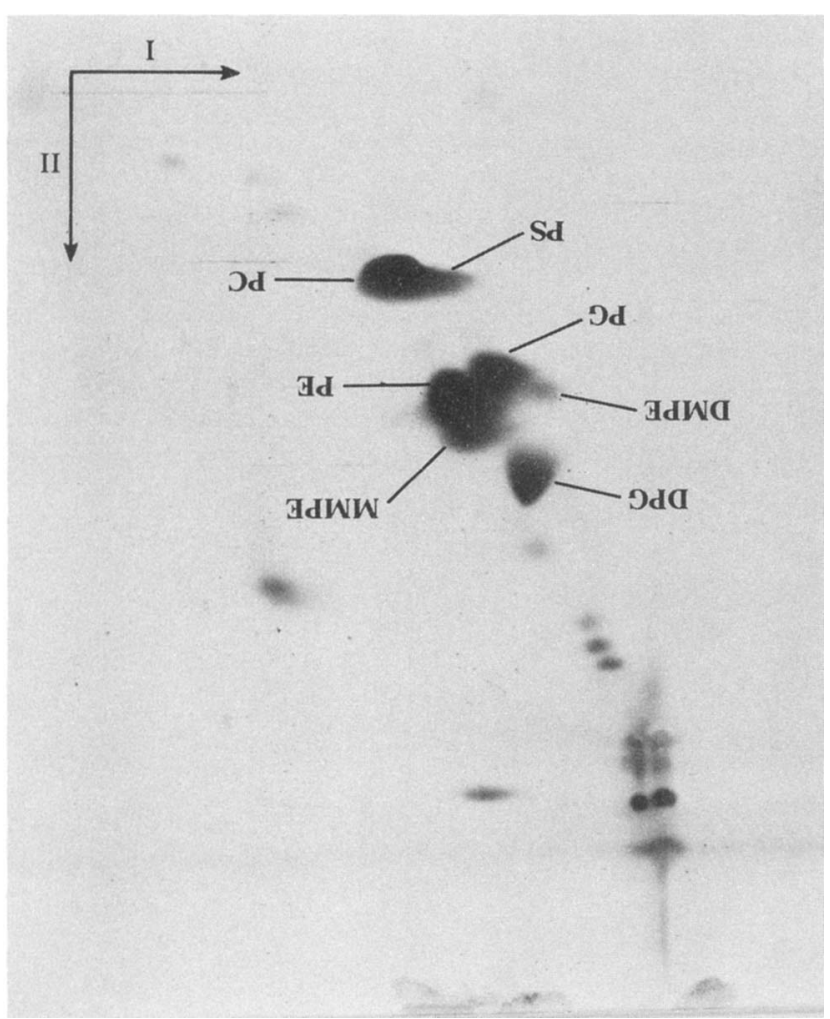

Fig. 3. Two-dimensional TLC analysis of the lipid classes in whole bacteria (strain AK631). Abbreviations as Fig. 2. The spot labelled DMPE was only tentatively identified as phosphatidyl- $N, N$ dimethylethanolamine.

specific signals for monounsaturated fatty acid groups and phosphocholine and phosphomonomethylethanolamine groups in these compounds. Comparison with synthetic standards confirmed these identifications (data not shown).

In order to look for differences in the lipid composition of inner or outer membranes of the wild-type and mutant strains, we separated the two membranes of the freeliving cells. Analysis of the fatty acid composition of membranes from strains Rm41 (wild-type), AK 1492 $\left(\mathrm{Nod}^{+} \mathrm{Fix}^{-}\right)$and $\mathrm{ZB1} 38$ (Nod-', with a deletion in the megaplasmid), gave similar results for the outer and the inner membranes (Table 3).

Analysis of the lipid classes of the two membranes of R. meliloti revealed that both fractions contain TG, DG, DPG, PE, MMPE, DMPE, PG, PC, small amount of PS and traces of lysophospholipid (LPL). In the inner membrane, there was much more DPG than in the outer membrane (Table 4; Fig. 4). Again, no significant differences were found in the lipid composition of the three strains Rm41, AK1492 and ZB138 (Fig.4).

Analysis of the fatty acid composition in the different lipid classes from the wild-type strain Rm41 (Table 5) indicated few differences in the fatty acid contents of the 
Table 3. Analysis of the fatty acids from the outer and inner membranes of the wild-type strain $R m 41$ and mutants AK1492 and ZB138

\begin{tabular}{|c|c|c|c|c|c|c|}
\hline \multirow{3}{*}{$\begin{array}{l}\text { Fatty } \\
\text { acid }\end{array}$} & \multicolumn{6}{|c|}{ Percentage total fatty acids } \\
\hline & \multicolumn{2}{|c|}{$\begin{array}{c}\mathrm{Rm}_{41} \\
\left(\mathrm{OD}_{540}=0.6\right)\end{array}$} & \multicolumn{2}{|c|}{$\begin{array}{c}\mathrm{AK} 1492 \\
\left(\mathrm{OD}_{540}=0 \cdot 7\right)\end{array}$} & \multicolumn{2}{|c|}{$\begin{array}{c}\mathrm{ZB138} \\
\left(\mathrm{OD}_{540}=0 \cdot 6\right)\end{array}$} \\
\hline & Outer & Inner & Outer & Inner & Outer & Inner \\
\hline $16: 0$ & $6 \cdot 5$ & $6 \cdot 3$ & $4 \cdot 7$ & $4 \cdot 1$ & 3.7 & 3.4 \\
\hline $16: 1(9 c)$ & 0.7 & 0.7 & 0.6 & $0 \cdot 6$ & 0.7 & $1 \cdot 3$ \\
\hline $16: 2$ & 1.0 & $0 \cdot 3$ & 0.3 & 0.2 & $0 \cdot 3$ & $0 \cdot 2$ \\
\hline $17: c y$ & - & 0.2 & 0.2 & 0.2 & - & $0 \cdot 2$ \\
\hline $18: 0$ & $6 \cdot 2$ & $5 \cdot 3$ & $4 \cdot 4$ & $4 \cdot 0$ & $3 \cdot 7$ & 0.8 \\
\hline $18: 1(11 c)$ & $80 \cdot 4$ & $80 \cdot 4$ & $83 \cdot 4$ & $83 \cdot 8$ & 89.6 & 91.5 \\
\hline $19:$ cy & $5 \cdot 3$ & $6 \cdot 4$ & 5.9 & 6.8 & $2 \cdot 0$ & $2 \cdot 3$ \\
\hline
\end{tabular}

Table 4. Analysis of lipid classes in the outer and inner membranes of strain Rm4I

The percentage compositions are expressed in terms of the percentage of total fatty acids

\begin{tabular}{lrr}
\hline \hline & \multicolumn{2}{c}{$\begin{array}{c}\text { Percentage of } \\
\text { each lipid class }\end{array}$} \\
\cline { 2 - 3 } & Outer & Inner \\
\hline TG & 1.4 & $1 \cdot 3$ \\
DG & $4 \cdot 0$ & $3 \cdot 2$ \\
DPG & $4 \cdot 1$ & $8 \cdot 4$ \\
MMPE & $10 \cdot 3$ & $9 \cdot 1$ \\
PE + DMPE & 36.0 & 35.3 \\
PG & 13.8 & 16.3 \\
PC & 25.5 & $25 \cdot 3$ \\
PS & 3.7 & 0.5 \\
LPL & 1.1 & $0 \cdot 4$ \\
\hline \hline
\end{tabular}

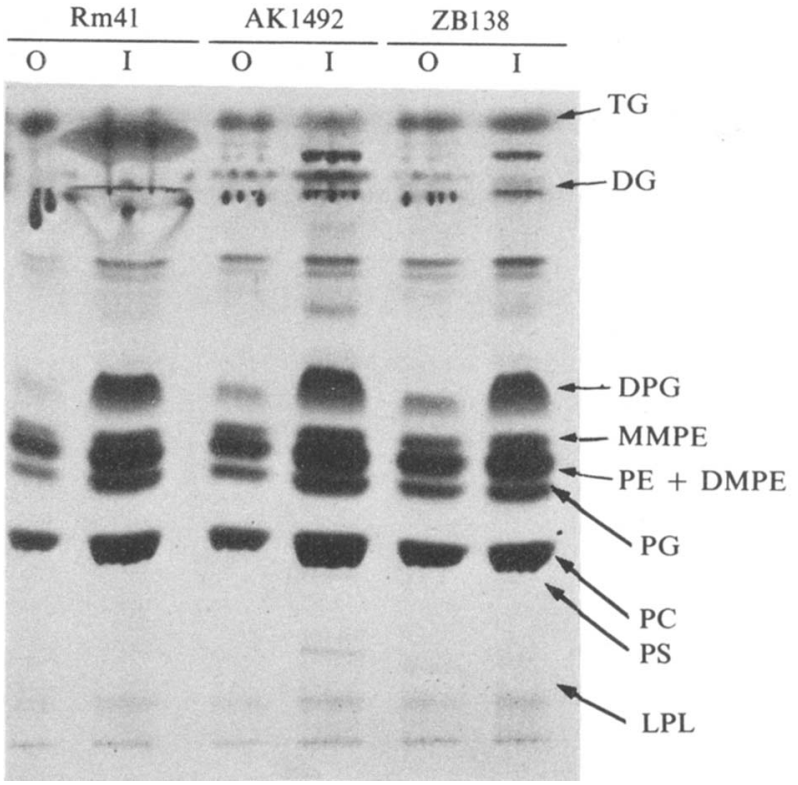

Fig. 4. Lipid classes in the outer $(\mathrm{O})$ and inner (I) membranes of strains RM41, AK1492 and ZB138, as determined by TLC. The inner membrane contains more DPG than the outer membrane. LPL, lysophospholipid; other abbreviations as Fig. 2.

outer and inner membranes. For the major classes, DPG, PE, PC, the amount of vaccenic acid was always high, but there was no difference in the fatty acid content of these different lipid classes with the exception that the minor classes were more unsaturated in the inner membrane than in the outer one. Addition of luteolin to the bacteria had no detectable effect on the lipid composition of either the whole bacteria (Fig. 2), or the separated membranes (data not shown).

In conclusion, the lipid classes of the two membranes were slighty different for the same strain, but were

Table 5. Fatty acid composition of different lipid classes in the outer and inner membranes of strain Rm4I

$$
\text { tr., Trace }
$$

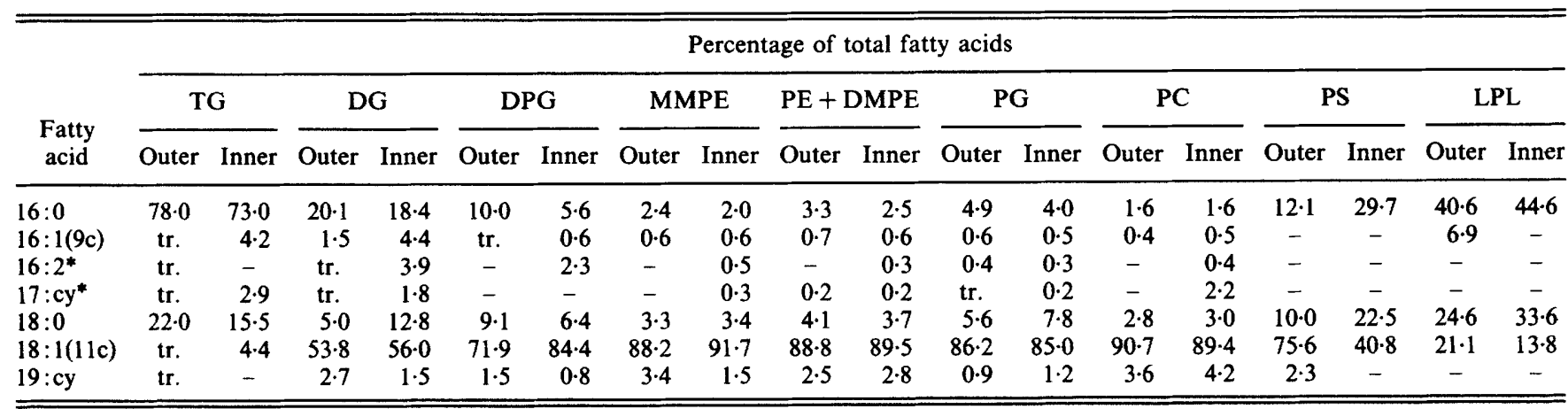

* Tentatively identified as 16:2 and 17:cy. 


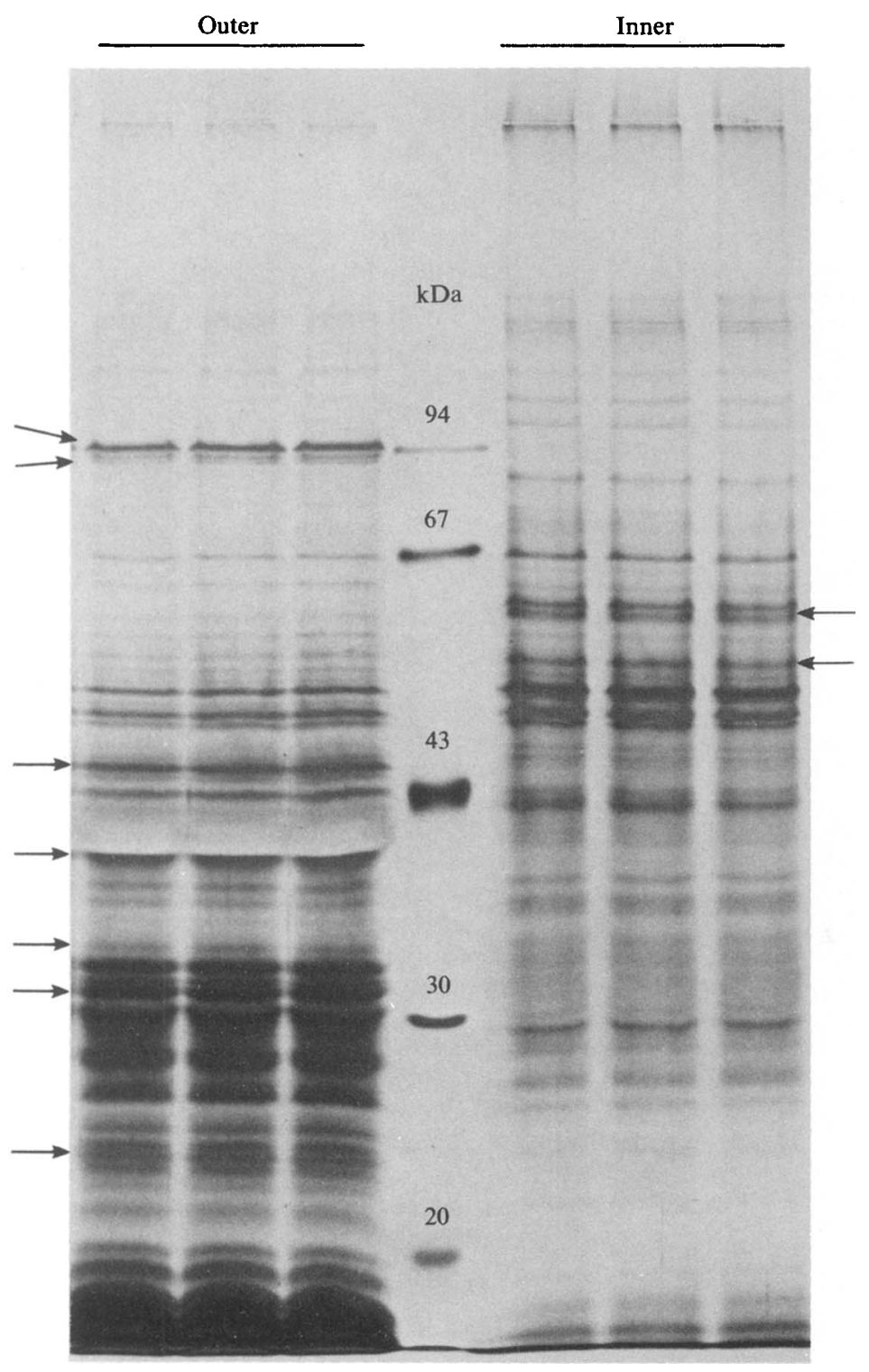

Fig. 5. Protein pattern of the outer and inner membranes in strain $\mathrm{Rm} 41$ as analysed by SDSPAGE. The protein patterns of these two membranes were different; examples are indicated by arrows. There were three replicates of each analysis. essentially the same in the wild-type strain and in the mutants studied. Luteolin induction had no detectable effect.

\section{Protein composition of inner and outer membranes in} wild-type and nod mutants of $R$. meliloti

The protein content increased during the exponential phase, with a maximum of $64 \mu \mathrm{g}$ protein (ml culture) $)^{-1}$ for $\mathrm{OD}_{540}=1 \cdot 1$, and then rapidly decreased in the stationary phase. The same result was obtained with the mutants. Total membrane proteins represented $27 \%$ of the total proteins. One-third of these membrane proteins was in the outer membrane, and two-thirds in the inner membrane.
The protein patterns of the outer and the inner membranes were very different, as seen in Fig. 5. Many bands from the two membranes co-migrated, but a number of bands seem to be specific for one or the other of the membranes.

The protein pattern was analysed not only from the top of the peak representing the inner membrane but also from the neighbouring fractions. Differences in the protein pattern of the inner membrane were detected (Fig. 6). For instance, bands at $50 \mathrm{kDa}$ were far more concentrated in the heaviest fractions while bands at $35 \mathrm{kDa}$ only appeared in the lightest ones. These variations in protein composition through different fractions corresponding to the inner membrane were found consistently in the two wild-type strains studied 


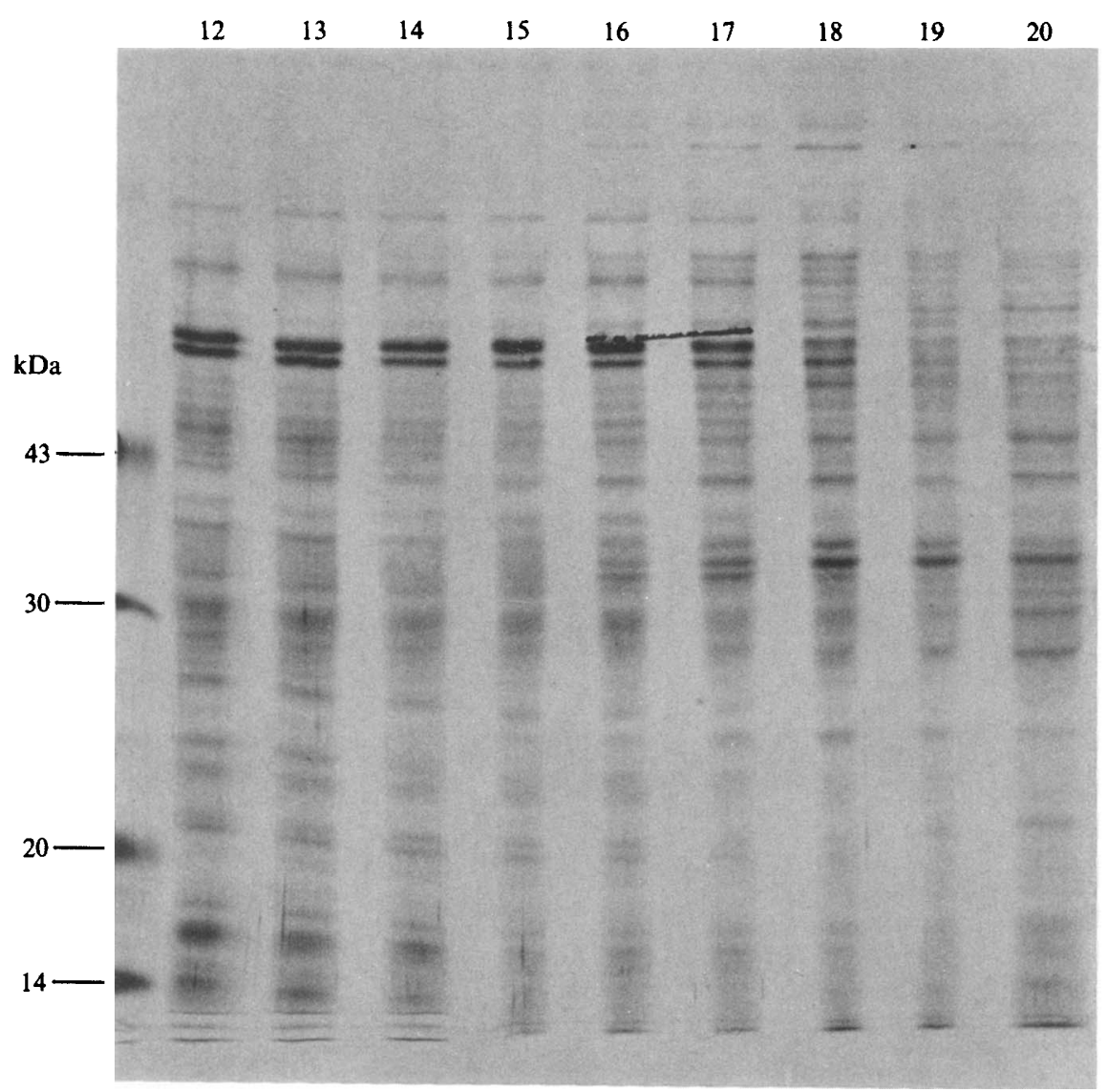

Fig. 6. SDS-PAGE of sucrose gradient fractions numbered from 12 to 20 corresponding to the inner membrane of the wild-type strain AK631.

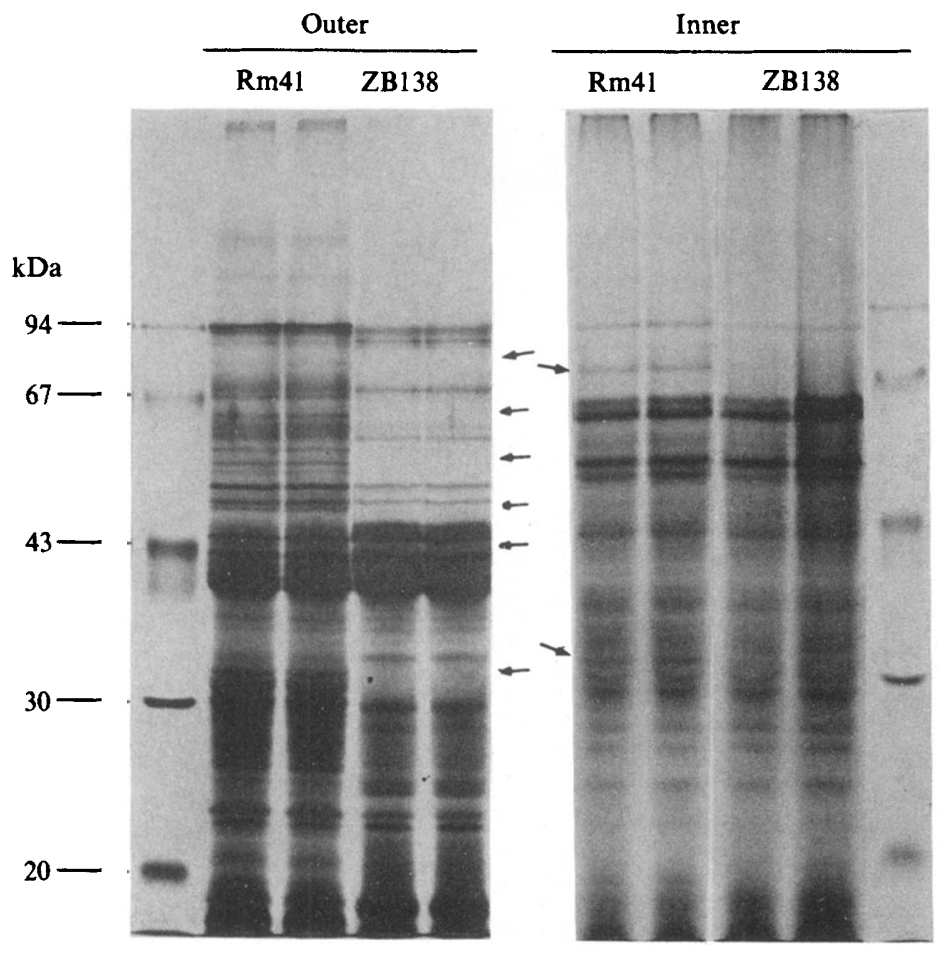

Fig. 7. Protein pattern of the outer and inner membranes of strains Rm41 and ZB138 as analysed by SDS-PAGE. Differences are indicated by arrows. Each analysis was performed twice. 
(a) Inner membrane

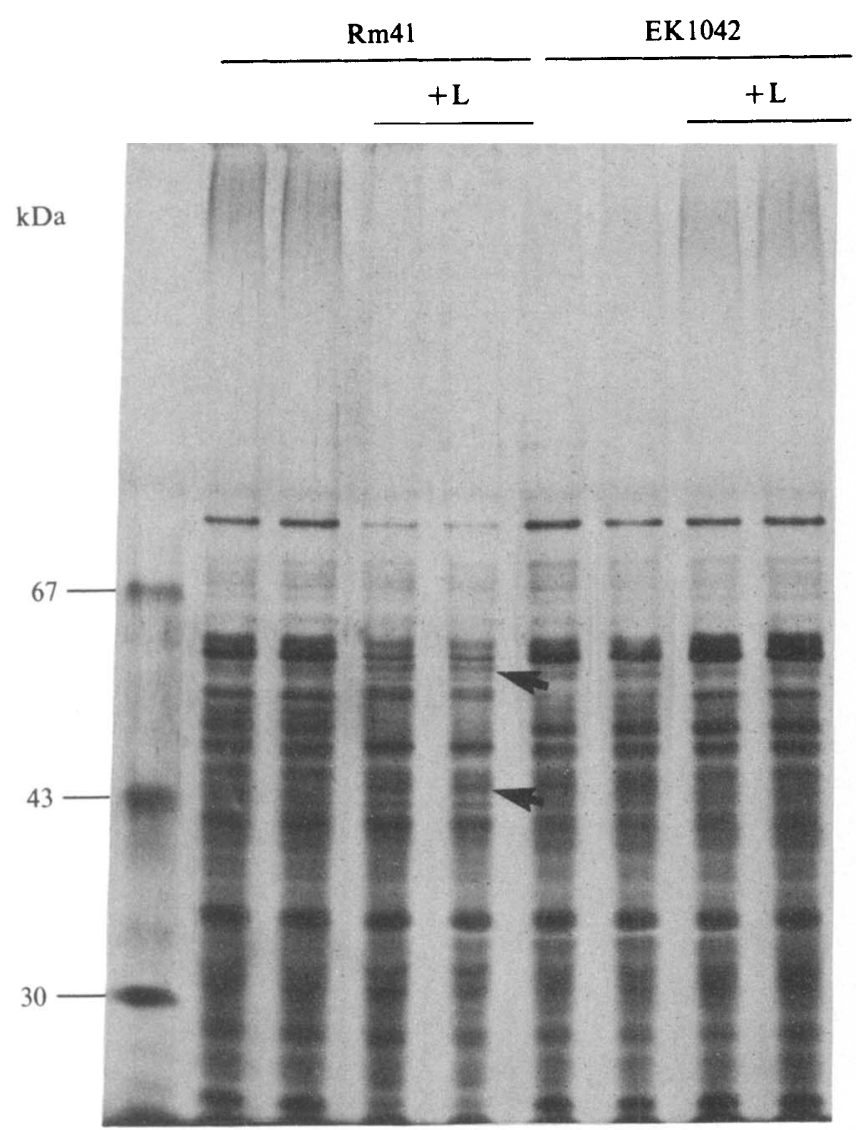

(c) Outer membrane

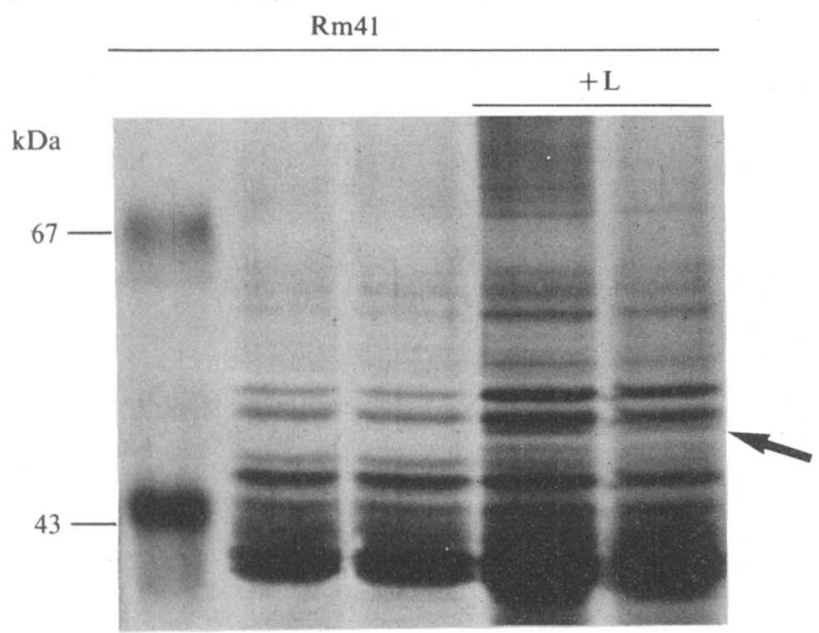

(Rm41 and AK631), which, on the other hand, showed almost completely identical protein patterns (data not shown). These differences may be due either to nonhomogeneous breakdown or to lateral heterogeneity of the inner membrane. The outer membrane showed exactly the same protein pattern through all fractions (b) Outer membrane

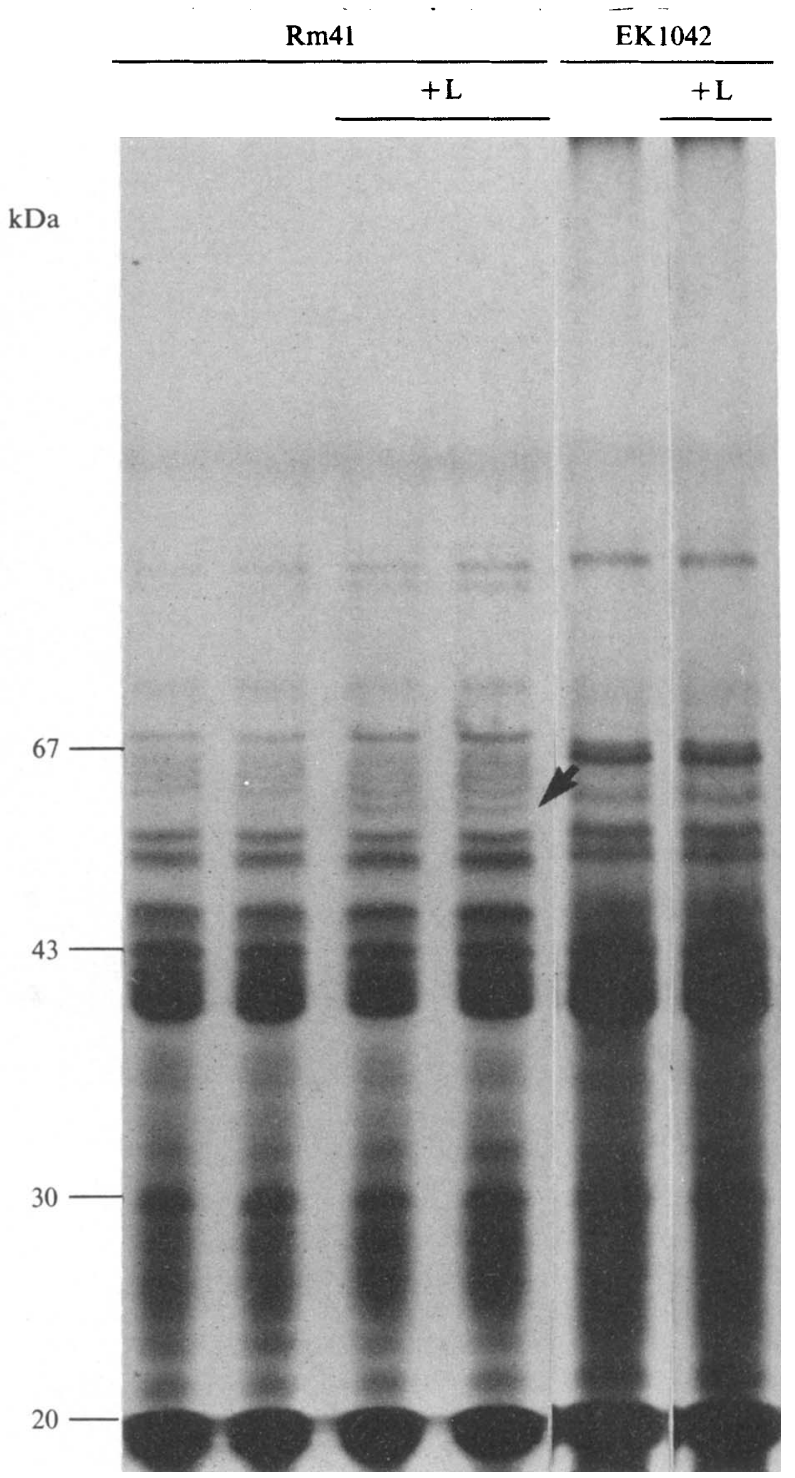

Fig. 8. Protein pattern of the inner (a) and the outer ( $b$ and $c$ ) membranes of the wild-type strain Rm41 and the mutant EK 1042 (nodC::Tn5) with $(+\mathrm{L})$ or without luteolin. The new bands are indicated by arrows. The Western gel $(c)$ was made with more dilute protein.

corresponding to this membrane in the gradient (data not shown).

The proteins of the inner and outer membranes of the wild-type strain $\mathrm{Rm} 41$ were compared with those of the ZB138 mutant. As seen in Fig. 7, differences were found between the protein patterns of these strains, especially 


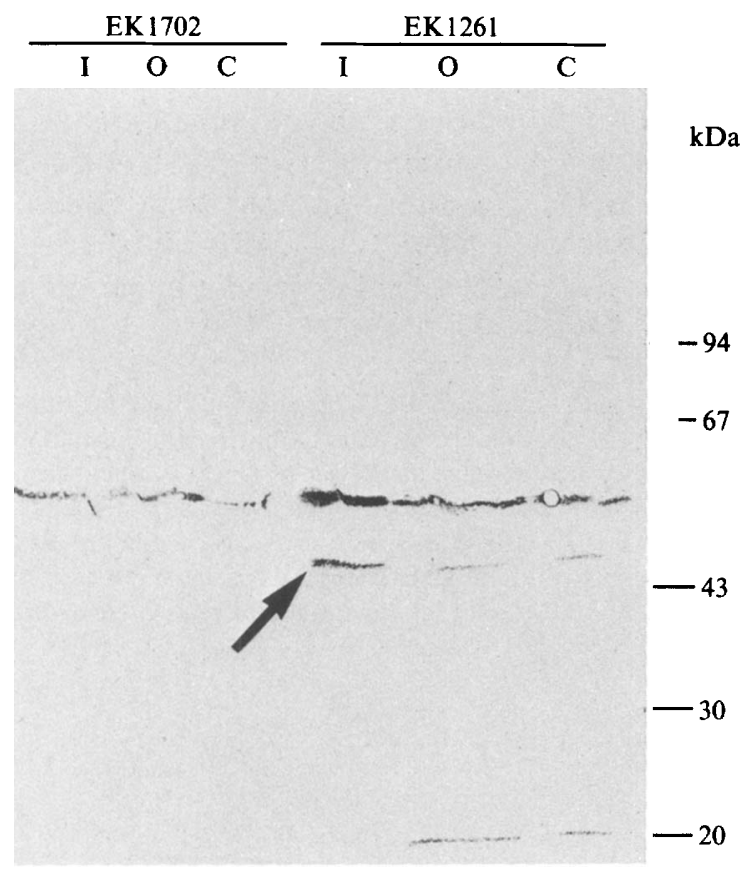

Fig. 9. Western blot analysis of the wild-type strain EK1261 and the nodC mutant EK 1702 (grown with luteolin and both overexpressing the nod genes). Samples with antibodies against NodC in the inner membrane (I), the outer membrane $(\mathrm{O})$ and the pellet $(\mathrm{C})$ correspond to the heaviest fractions of the outer membrane. The arrow indicates the NodC protein.

in the outer membrane. In the outer membrane of strain ZB138 more than 10 bands were lacking or very weakly expressed in the molecular mass range between 40 and $90 \mathrm{kDa}$. Several differences were also found in the patterns of the inner membrane proteins. Our data suggest that the DNA region deleted in strain ZB138 encodes numerous membrane proteins, since even before luteolin treatment several bands were lacking. In contrast, the $\mathrm{Nod}^{+} \mathrm{Fix}^{-}$mutants tested (AK985, AK1492 and TF178), showed no detectable differences in the protein patterns of the two membranes (data not shown). A more extensive investigation of the protein pattern in several mutants is in progress, but the complexity of the protein pattern makes the clear characterization of changes very difficult, without a more powerful tool such as antibodies.

In order to correlate the appearance of new membrane proteins with the induction of nod genes, the wild-type strain $\mathrm{Rm} 41$ was induced with $10 \mu \mathrm{M}$-luteolin for $8 \mathrm{~h}$. Then the protein pattern was followed in both the outer and the inner membranes and compared with that of the untreated samples. As seen in Fig. 8, the luteolin treatment did not bring about drastic changes in the protein pattern in the two membranes. The appearance of two new bands was observed: one at about $60 \mathrm{kDa}$ and the other at $44 \mathrm{kDa}$ (but this last band was often hidden in the outer membrane by other major proteins). These two bands were not detected after luteolin treatment in the mutant EK 1042 carrying a Tn5 insertion in the nodC gene.

To see if the band at $44 \mathrm{kDa}$ could represent the NodC protein, which has the same molecular mass (Schmidt $e t$ al., 1984), immunoblots were performed using an antiNodC protein recognizing the main hydrophobic domain. Because the NodC protein is only weakly expressed in the wild-type strain (Schmidt et al. 1984), for these experiments we used strain EK1261, which overexpresses the nod genes. As seen in the immunoblot (Fig. 9), a band migrating at $44 \mathrm{kDa}$ was detected both in the outer and in the inner membrane samples. If a nodC::Tn5 mutant overexpressing the nod genes (EK 1702) was used, no immunoreaction was observed in the $44 \mathrm{kDa}$ region with either of the two membranes. One major non-specific band was detected in all samples (Fig. 9), which was previously seen also by John et al. (1985). In agreement with John et al. (1988), the positive immunoreaction band at $44 \mathrm{kDa}$ could be seen in the total cell extracts but not in the cytosol (data not shown).

\section{Discussion}

In this paper, we have shown that $R$. meliloti contains not only the three characteristic phospholipids of most Gram-negative bacteria (DPG, PG and PE), but also PC. Interestingly, PC has also been found in several other Gram-negative bacteria that establish symbiotic or pathogenic relationships with plants, such as some members of the Pseudomonaceae (Wilkinson, 1988), $A$. tumefaciens and other Rhizobium species (Thompson et al., 1983). PC is probably synthesized by progressive methylation of the amino group of PE, since the two intermediary metabolic compounds of the pathway, MMPE and DMPE (Thompson et al., 1983) were also detected. Having in mind that $P C$ is a major lipid in the non-photosynthetic membranes of plant cells, where it plays a crucial role in lipid metabolism (Roughan \& Slack, 1983), one can speculate that its presence in the bacterial membrane might have some importance during the development of symbiosis.

DPG was found at higher concentration in the inner membrane of $R$. meliloti. Because DPG has been shown to be tightly linked to cytochrome oxidase (Powel \& Abramovitch, 1985), which is located in the inner membrane of Gram-negative bacteria, it can be considered as a good marker for this membrane.

Despite the fact that the Nod factor always contains a fatty acid attached to the sugar backbone, no significant 
changes in the lipid composition were detected at the membrane level, and none of the $\mathrm{Nod}^{-}$mutants tested after luteolin induction were affected in their fatty acid or glycerolipid composition. Perhaps the synthesis of the fatty acid part of the Nod factors is a very discrete event, occurring largely independently from the main biosynthetic pathway for the lipids of bacterial membranes.

This paper shows that, as expected, the inner and outer membranes have very different protein compositions. Even if this work constitutes only a first step in the analysis of these differences, it is clear that several bands are specific for each of the membranes.

The protein pattern was very different in the Nod $^{-}$ mutant ZB138, which carries a large deletion in the pRme41 b megaplasmid, suggesting that numerous membrane proteins are encoded by the megaplasmid DNA. When the nod genes were induced by luteolin, slight but significant changes could be detected in the membrane protein pattern. Two new bands appeared after luteolin treatment: in the outer and in the inner membranes at about $60 \mathrm{kDa}$ and at $44 \mathrm{kDa}$. These two bands were not detected after luteolin treatment in the mutant EK1042, which carries a $\operatorname{Tn} 5$ insertion in the nodC gene. The $44 \mathrm{kDa}$ band was shown to correspond to the NodC protein. For the $60 \mathrm{kDa}$ band, the interpretation is more difficult because a $60 \mathrm{kDa}$ luteolin-dependent membrane protein has not been described before (Kondorosi, 1990). The product of the nod $M$ gene has a molecular mass of $66 \mathrm{kDa}$ (Baev et al., 1991), but this gene is located in a different operon. One possibility is that the $60 \mathrm{kDa}$ protein requires the nodC product for attachment to the membranes, or that downstream of the operon containing nodC there is another, yet unidentified gene with a $60 \mathrm{kDa}$ product. The NodC protein is implicated in the synthesis of Nod factors (Lerouge et al., 1990), exported from the bacteria to the host plant. This protein exhibits homology with chitin synthase and is supposed to be involved in the synthesis of the oligosaccharide backbone of the signal molecule (Bulawa \& Wasco, 1991). The NodC sequence (Török et al., 1984) reveals a strongly hydrophobic domain at the $\mathrm{C}$-terminal end and the work by John et al. (1988) has shown that the anti-NodC antibodies can recognize a polypeptide at $44 \mathrm{kDa}$ at the external side of the bacterial membrane. It was concluded that the NodC protein is located in the outer membrane and that the hydrophobic immunoreactive portion of the protein represents an extracellular domain which can be detached by trypsin.

Our work has confirmed that at least part of the NodC protein is located in both of the two bacterial membranes, suggesting that this protein could also play a role in transport of the Nod factor through the membranes. From the fact that we were unable to detect NodC protein in the cytosol, we cannot exclude completely that it may be present in the cytosol also. At the same time, the NodA and NodB proteins, which are also likely to be involved in the synthesis of the Nod factor, have been demonstrated to be cytosolic proteins (John et al., 1985). Therefore, the exact localization of the NodC protein, its distribution in the bacterial cell and its possible role in the transport of the Nod factors remain important open questions.

We thank Dr E. Kondorosi for construction of bacterial strains for this work, and also for discussion and modification of the manuscript. We wish also to acknowledge the advice of Dr A. Pugsley during the course of this work, Dr J. C. Beloeil for the NMR analysis, and Drs P. Varenne and B. C. Das for mass spectrometry. We thank also R. Boyer for photographic work and C. Deforeit for typing. We are grateful to Drs M. John and J. Schmidt for the antibodies against NodC protein.

\section{References}

Banfalvi, Z., Sakanyan, V., Koncz, C., Kiss, A., Dusha, I. \& KONDOROSI, A. (1981). Location of nodulation and nitrogen fixation genes on a high molecular weight plasmid of R. meliloti. Molecular and General Genetics 184, 318-325.

Baev, N., Endre, G., Petrovics, G., Banfalvi, Z. \& Kondorosi, A. (1991). Six nodulation genes of nod box locus 4 in Rhizobium meliloti are involved in nodulation signal production: nodM codes for Dglucosamine synthetase. Molecular and General Genetics 228, 113 124.

Bligh, E. G. \& DYER, W. J. (1959). A rapid method of total lipid extraction and purification. Canadian Journal of Biochemistry and Physiology 37, 911-917.

BLUM, H., HidBuRG, B. \& GRoss, J. (1987). Improved silver staining of plant proteins, RNA and DNA in polyacrylamide gels. Electrophoresis 8, 93-99.

BRADFORD, M. M. (1976). A rapid and sensitive method for the quantitation of microgram quantities of protein utilizing the principle of protein-dye binding. Analytical Biochemistry 72, 248254.

Braun, V. \& HaNtKe, K. (1974). Biochemistry of bacterial cell envelopes. Annual Review of Biochemistry 43, 89-121.

Bulawa, C. E. \& Wasco, W. (1991) Chitin and nodulation. Nature, London 353, 710.

ForRai, T., Vincze, E., Banfalvi, Z., Kiss, G. B., Randhawa, S. \& KoNDOROSI, A. (1983). Localization of symbiotic mutations in Rhizobium meliloti. Journal of Bacteriology 153, 635-643.

Gerson, T. \& PATEL, J. J. (1975). Neutral lipids and phospholipids of free-living and bacteroid forms of 2 strains of Rhizobium infective on Lotus pedunculatus. Applied Microbiology 30, 193-198.

Gerson, T., Patel, J. J. \& Nixon, L. N. (1975). Some unusual fatty acids of Rhizobium. Lipids 10, 134-139.

JoHN, M., SCHMidT, J., WieneKe, U., Kondorosi, E., Kondorosi, A. \& SCHELL, J. (1985). Expression of the nodulation gene nodC of Rhizobium meliloti in Escherichia coli: role of the nodC gene product in nodulation. EMBO Journal 4, 2425-2430.

John, M., Schmidt, J., Wieneke, L., KRussmanN, H. D. \& Schell, J. (1988). Transmembrane orientation and receptor like structure of the Rhizobium meliloti common nodulation protein NodC. EMBO Journal 7, 583-588.

KATES, M. (1986). Isolation, analysis, identification of lipids. In Techniques in Lipidology, 2nd edn, p. 464. Edited by R. H. Burdon \& P. H. Knippenberg. Amsterdam: Elsevier.

KondorosI, A. (1990). Rhizobium-legume interactions: nodulation genes. In Plant-Microbe Interactions. Molecular and Genetic Perspectives, vol. 3, pp. 383-420. Edited by T. Kosuge \& E. W. Nester. New York: McGraw-Hill. 
Kondorosi, A., Svab, Z., Kiss, G. B. \& Dixon, R. A. (1977). Ammonia assimilation and nitrogen fixation in Rhizobium meliloti. Molecular and General Genetics 151, 221-226.

Kondorosi, E., Gyuris, J., Schmidt, J., John, M., Duda, E., Hoffmann, B., Schell, J. \& Kondorosi, A. (1989). Positive and negative control of nod gene expression in Rhizobium meliloti is required for optimal nodulation. EMBO Journal 5, 1331-1340.

Kondorosi, E., Pierre, M., Cren, M., haumann, U., Buire, M., HofFMANN, B., SCHELl, J. \& KoNDOROSI, A. (1992). Identification of NolR, a negative transacting factor controlling the nod regulon in Rhizobium meliloti. Journal of Molecular Biology 223, 885-896.

Lerouge, P., Roche, P., Faucher, C., Maillet, F., Truchet, G., Prome, J. C. \& Denarie, J. (1990). Symbiotic host specificity of Rhizobium meliloti is determined by a sulphated and acylated glucosamine oligosaccharide signal. Nature, London 344, 781-784.

LUGTENBERG, B. J. J. \& VAN ALPHEN, L. (1983). Molecular architecture of the outer membrane of $E$. coli and other Gram-negative bacteria. Biochimica et Biophysica Acta 737, 51-115.

DE MAAGD, R. (1989). Studies on the cell surface of the root-nodulating bacterium Rhizobium leguminosarum. PhD. thesis, University of Leiden, Holland.

DE MAAGD, R. \& Lugtenberg, B. (1986). Fractionation of Rhizobium leguminosarum cells into outer membrane, cytoplasmic membrane, periplasmic and cytoplasmic components. Journal of Bacteriology 167, 1083-1985.

de MaAgd, R., van Rossum, A. C. \& Lugtenberg, B. J. J. (1988), Recognition of individual strains of fast-growing rhizobia by using profiles of membrane proteins and lipopolysaccharides. Journal of Bacteriology 170, 3782-3785.

MaCKenzie, S. L., LAPP, M. S. \& Chicd, J. J. (1979). Fatty acid composition of Rhizobium spp. Canadian Journal of Microbiology $\mathbf{2 5}$, 68-74.

MANGOLD, H. K. (1961). Thin layer chromatography of lipids. I Journal of the American Oil Chemist's Society 38, 708-727.

MANGOLD, H. K. (1964). Thin layer chromatography of lipids. II. Journal of the American Oil Chemist's Society 38, 762-773.

Metcalfe, L. D., Schmitz, A. A. \& Pelka, J. R. (1966). Rapid preparation of fatty acids esters from lipids for gas chromatographic analysis. Analytical Chemistry 38, 514-515.

Miller, R. W. \& Tremblay, P. A. (1983). Cytoplasmic membrane of Rhizobium meliloti bacteroids. I. Alterations in lipid composition, physical properties, and respiratory proteins. Canadian Journal of Biochemical Cell Biology 61, 1334-1340.

OsBorn, M. J. \& WU, H. C. P. (1980). Proteins of the outer membrane of Gram-negative bacteria. Annual Review of Microbiology 34, 369 422 .
Osborn, M. J., Gander, J. E., Parisi, E. \& Carson, J. (1972) Mechanism of assembly of the outer membrane of Salmonella typhimurium. Journal of Biological Chemistry 247, 3962-3972.

Peters, N. K., Frost, J. W. \& LoNG, S. R. (1986). A plant flavone, luteolin, induces expression of Rhizobium meliloti nodulation genes. Science 233, 977-980.

Powel, G. L. \& ABramovitch, D. A. (1985). Function of cardiolipin in the cytochrome $\mathrm{C}$ oxidase. Federation Proceedings of the American Society of Experimental Biology 44, 478-485.

Robertson, J. G., Wells, B., Brewin, N. J., Wood, E., KNight, C. D. \& Downie, J. A. (1985). The legume-Rhizobium symbiosis: a cell surface interaction. Journal of Cell Sciences, suppl. 2, 317331.

Roughan, P. G. \& SLACK, C. R. (1983). Cellular organization of glyceride metabolism. Annual Review of Plant Physiology 33, 97132.

SCHMidt, J., John, M., Kondorosi, E., Kondorosi, A., Wieneke, U., SCHRODER, G., SCHRODER, J. \& SCHELL, J. (1984). Mapping of the protein-coding regions of Rhizobium meliloti common nodulation genes. EMBO Journal 3, 1705-1711.

Schultze, M., Quiclet-Sire, J. E., Kondorosi, E., Virelizier, H., GlushKa, J. N., Endre, G., Gero, S. D. \& Kondorosi, A. (1992). Rhizobium meliloti produces a family of sulfated lipooligosaccharides exhibiting different degrees of plant host specificity. Proceedings of the National Academy of Sciences of the United States of America 89, 192-196

Thompson, E. A., Kaupman, A. E., Johnston, N. C. \& Goldfine, H. (1983). Phospholipids of Rhizobium meliloti and Agrobacterium tumefaciens: lack of effect of Ti plasmid. Lipids 18, 602-606

TöröK, I., Kondorosi, E., STEPKowski, T., PosfaI, J. \& Kondorosı, A. (1984). Nucleotide sequence of Rhizobium meliloti nodulation genes. Nucleic Acids Research 12, 9509-9524.

Towbin, H., Staehelin, T. \& Gordon, J. (1979). Electrophoretic transfer of proteins from polyacrylamide gels to nitrocellulose sheets : procedure and some applications. Proceedings of the National Academy of Sciences of the United States of America, 76, 4350-4354.

Trémolières, A. \& Lepage, M. (1971). Changes in lipid composition during greening of etiolated pea seedling. Plant Physiology 47, 329 334

Varenne, P., Das, B. C., Polonsky, J. \& Tence, M. (1985). Chemical ionization and fast atom bombardment mass spectometry of platelet activating factor (PAF-acether) and related phospholipids. Biomedical Mass Spectrometry 12, 6-10.

WILKINSON, S. G. (1988). Gram negative bacteria. In Microbial Lipids I, pp. 299-488. Edited by C. Ratledge \& S. G. Wilkinson. London: Academic Press. 